\title{
Productivity of maize (Zea mays L.) as affected by varieties and sowing dates
}

\author{
Dil Bahadur Gurung ${ }^{1}$, Balram Bhandari ${ }^{2}$, Jiban Shrestha ${ }^{1,2}$ \& Mahendra Prasad Tripathi ${ }^{2}$ \\ ${ }^{1}$ Nepal Agricultural Research Council, Singh Darbar Plaza, Kathmandu, Nepal \\ ${ }^{2}$ Nepal Agricultural Research Council, National Maize Research Program, Chitwan, Nepal
}

\begin{abstract}
Genotypic yield potential of maize varieties is greatly affected by sowing dates. In order to investigate the effects of sowing dates and varieties on the grain yield of maize, the field experiment was carried out at research field of National Maize Research Program (NMRP), Rampur, Chitwan, Nepal from April 2009 to March 2010. Three varieties namely Rampur Composite, Arun-2 and Gaurav were sown at every week. The results of experiment showed that interaction effect of variety and sowing date on grain yield of maize was significant. Rampur Composite produced highest grain yield (6.1 $\mathrm{t} / \mathrm{ha}$ ) in August and lowest yield (2.6 t/ha) in May. Similarly Arun-2 produced highest yield (4.6 t/ha) in August and lowest yield (2.1 t/ha) in May. Gaurav produced highest grain yield (5.1 t/ha) in September followed by 4.9, 4.8 and $4.6 \mathrm{t} / \mathrm{ha}$ in February, July and August respectively and lowest yield (1.5 t/ha) in November. The sowing date was highly significant on grain production. The highest grain production was $5.1 \mathrm{t} / \mathrm{ha}$ in August followed by in February (4.9 t/ha), September (4.6 t/ha) and March (4.4 t/ha) respectively. The lowest grain yield was produced in May (2.4 t/ha). Therefore it was concluded that August planting was best for higher grain production of maize varieties (Rampur Composite, Arun-2 and Gaurav) in terai region of Nepal.
\end{abstract}

\section{Article History}

Received 12 July 2018

Accepted 10 December 2018

Keyword

Grain yield

Sowing dates

Varieties

\section{Introduction}

Maize (Zea mays L.) is the second most important staple crops after rice both in terms of area and production. Its area, production, and productivity in Nepal are 882395 ha, $2145291 \mathrm{t}$, and $2431 \mathrm{~kg}$ (MOAD 2016) respectively. This productivity is very low compared to that of neighboring countries. For optimum production seed must be sown on proper time. Considerable reduction can occur in yield if the crop sown to early or too late (Chaudry, 1994). Ismail (1996) reported that early sowing of maize lead to an increased maize yield. Either early planting or late planting can result in lower yield because the probability exists that unfavourable climatic conditions can occur after planting or during the growing season. In order for crop to best utilize moisture, nutrient and solar radiation, they must be grown from optimum sowing dates. Nepal is a small country with large environmental variation. Throughout the seasons of a year, weather conditions fluctuate a lot. In this situation, the same varieties may perform differently in different seasons. 
For maximization of benefit to farmers, they have to grow best maize varieties in best season of that location. Tanaka and Hara (1974) in India reported that variation in maize grain yield is due to the reduction in 1000-seed weight when sowing was delayed to the end of October. Mascagni and Boquet (1996) studied the effect of sowing dates on performance of maize and concluded that delay in sowing reduced yield of maize. In Nepal very little work was done on the effect of sowing date and varieties on the performance of maize. The objective of this study was to determine the grain yield responses of maize to sowing dates and varieties.

\section{Materials and Methods}

\section{Description of experimental site}

The geographical location of the experiment site was located at $27^{\circ} 40^{\prime} \mathrm{N}$ latitude, $84^{\circ} 19^{\prime} \mathrm{E}$ and 228 masl and has sub tropical climate. The experimental soil was sandy silt loam, strongly acidic soil ( $\mathrm{pH} 5.0)$, medium in total nitrogen $(0.130 \%)$, high in soil available phosphorous (279 kg/ha), high in soil available potassium (215 kg/ha) and high in organic matter content (2.70\%) (NMRP, 2011).

\section{Meterological observation}

The meterological data in terms of temperature, rainfall and relative humidity during the crop growing period was given in Table 1.

Table 1. Meterological data at Rampur, chitwan, Nepal during 2009/10-2010/11

\begin{tabular}{|c|c|c|c|c|c|c|c|c|}
\hline \multirow[t]{3}{*}{ Month } & \multicolumn{4}{|c|}{ Mean temperature $\left({ }^{\circ} \mathrm{C}\right)$} & \multicolumn{2}{|c|}{$\begin{array}{l}\text { Total Rainfall } \\
(\mathrm{mm})\end{array}$} & \multicolumn{2}{|c|}{$\begin{array}{l}\text { Relative Humidity } \\
(\%)\end{array}$} \\
\hline & \multicolumn{2}{|c|}{2009} & \multicolumn{2}{|c|}{2010} & \multirow[t]{2}{*}{2009} & \multirow[t]{2}{*}{2010} & \multirow[t]{2}{*}{2009} & \multirow[t]{2}{*}{2010} \\
\hline & Maxi & Min & Maxi & Min & & & & \\
\hline April & 37.4 & 19.2 & 38.1 & 23.3 & 7.3 & 165 & 57.5 & 75.4 \\
\hline May & 35.4 & 22.5 & 35.2 & 25.4 & 274.2 & 193 & 72.3 & 77.5 \\
\hline June & 35.1 & 24.9 & 35.4 & 26.9 & 179.2 & 372 & 81.1 & 78.7 \\
\hline July & 33.5 & 29.7 & 33.5 & 26.5 & 455 & 115.0 & 83 & 87.4 \\
\hline August & 33.5 & 29.7 & 33.5 & 26.7 & 753 & 641.2 & 96 & 96.0 \\
\hline September & 32.8 & 29 & 32.8 & 25.8 & 126 & 523.2 & 90 & 87.9 \\
\hline October & 31.4 & 26.5 & 31.4 & 22.8 & 101 & 48.6 & 97 & 97.5 \\
\hline November & 27.1 & 21.6 & 27.1 & 17.0 & 0 & 0.0 & 99 & 98.8 \\
\hline December & 24 & 16 & 24.0 & 9.1 & 2.2 & 0.0 & 99 & 99.0 \\
\hline January & 20 & 10.3 & 23.9 & 8.5 & 0 & 0.0 & 94.6 & 100.5 \\
\hline February & 25.4 & 11.9 & 26.1 & 15.1 & 0 & 34.9 & 89.5 & 96.3 \\
\hline March & 33.1 & 19.1 & 31.1 & 18.9 & 0 & 34.4 & 82.2 & 83.2 \\
\hline
\end{tabular}

Experimental design and cultural practices

Three varieties namely Rampur Composite, Arun-2 and Gaurav were sown in every week from April to March. The design was randomized complete block design replicated four times. In each month, the planting was done at seven days intervals. Spacing $75 \mathrm{~cm}$ row to row and $25 \mathrm{~cm}$ plant to plant spacing was maintained and two to three seeds are sown and after two weeks thinned one plants/hill. Plot size was $6 \times 3.6 \mathrm{~m}$ out of which $5 \times 2.4$ was used to assess final harvest. Fertilizer @ FYM 10 t/ha and 12:60:40 kg NPK/ha was applied for each experiment. Half dose of nitrogen and full dose of phosphorous and potash was applied as 
basal dose at the time of final land preparation and remaining half of nitrogen was divided into two; one part applied at 20-24 and 40-45 days after sowing. Weeding and irrigation was done as per recommendations.

\section{Field measurements}

Grain yield $(\mathrm{kg} / \mathrm{ha})$ at $15 \%$ moisture content was calculated using fresh ear weight with the help of the below formula:

Where,

$$
\text { Grain yield }\left(\frac{\mathrm{kg}}{\mathrm{ha}}\right)=\frac{\text { F.W. }\left(\frac{\mathrm{kg}}{\mathrm{plot}}\right) \times(100-\mathrm{HMP}) \times \mathrm{S} \times 10000}{(100-\mathrm{DMP}) \times \mathrm{NPA}}
$$

F.W. = Fresh weight of ear in kg per plot at harvest

$\mathrm{HMP}=$ Grain moisture percentage at harvest

DMP = Desired moisture percentage, i.e. $15 \%$

$\mathrm{NPA}=$ Net harvest plot area, $\mathrm{m}^{2}$

$\mathrm{S}=$ Shelling coefficient, i.e. 0.8

This formula was also adopted by Carangal et al. (1971) and Shrestha et al. (2015) to adjust the grain yield $(\mathrm{kg} / \mathrm{ha})$ at $15 \%$ moisture content.

\section{Statistical analysis}

Data regarding the grain yield was statistically analyzed by combined analysis procedure to test differences among and within the different factors. The least significant difference (LSD) was used to separate the means of the main and interaction effects.

\section{Results and Discussion}

Varieties also showed highly significant effect on yield. Rampur Composite produced the highest $4.1 \mathrm{t} /$ ha yield which was as par with Gaurav (3.6 t/ha). Arun-2 produced the lowest $3.3 \mathrm{t} /$ ha (Figure 1). This results was similar to the results of Sadek et al. (1994) and Zaki et al. (1999) who reported that maize cultivars differed in their yield in India.

$\operatorname{LSD}(0.05)=0.4295, \quad$ SEM $=0.1171$ and $\mathrm{P}$ value $=0.01$

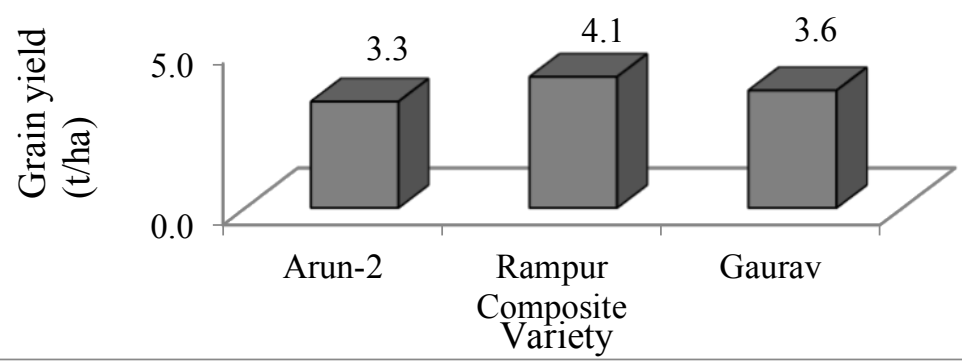

Figure 1. Pooled mean grain yield of different maize varieties in Rampur Chitwan

In 2009 Gaurav produced the highest yield (4.3 t/ha) and Arun-2 produced the lowest (3.3 t/ha). But in 2010 Rampur Composite produced the highest amount (4.1 t/ha) and Gaurav produced the lowest ( $3 \mathrm{t} / \mathrm{ha}$ ). There was highly significant effect of interaction of years and date of sowing on grain yield of maize (Table-2). The grain yield differed in yield.

Table 2. Interaction effect of years and variety on grain yield of maize in Rampur, Chitwan 


\begin{tabular}{lcccc}
\hline S.N. & Years & Arun-2 & $\begin{array}{c}\text { Varieties } \\
\text { Rampur composite }\end{array}$ & Gaurav \\
\hline 1. & $2009 / 10$ & 3.3 & 4.0 & 4.3 \\
2. & $2010 / 11$ & 3.3 & 4.1 & 3.0 \\
\hline LSD at $0.05=0.6074$ & & & \\
SEM $=0.1656$ & & & \\
P value $=0.01$ & & & \\
\hline
\end{tabular}

The highest production was $5.1 \mathrm{t} / \mathrm{ha}$ in August followed by February (4.9 t/ha), September (4.6 t/ha) and March (4.4 t/ha) respectively. The lowest yield was of month May (2.4 t/ha) (Figure 2). This results was confirmed with the findings of Dahmardeh and Dahmardeh (2010) who reported that the maximum grain yield ( $8.84 \mathrm{t} / \mathrm{ha}$ ) was obtained from the 5 August sowing date that was not statistically on a 20 July and 20 August. Winter maize has higher production potential. Crop receives longer sunshine duration, higher rate of photosynthesis and assimilates utilization occurs during winter season. Fertilizer use efficiency is higher in winter season. These factors contribute higher production during winter season.

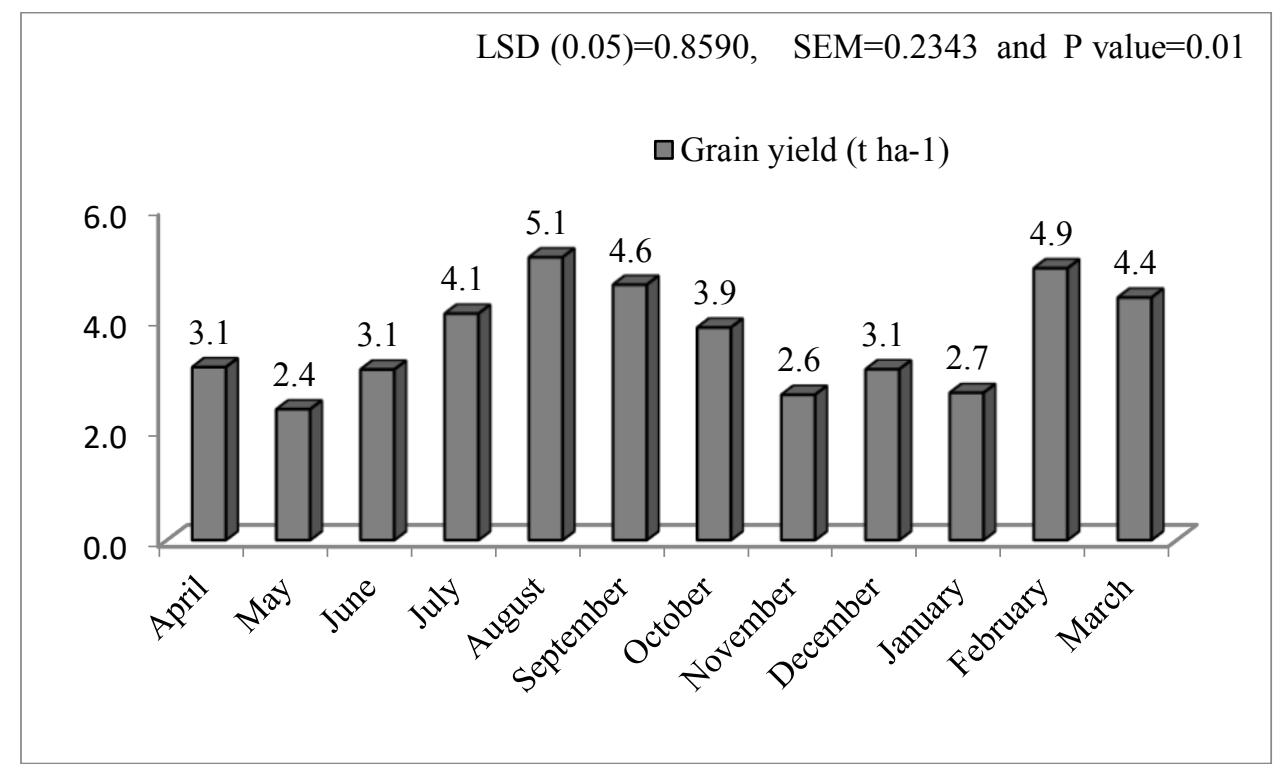

Figure 2. Effect of date of sowing (month) on grain yield of maize in Rampur Chitwan

Effect of interaction of variety and date of sowing (month) on grain yield of maize was found significant $(p \geq 0.05$ ) (Table 3 ). Arun-2 produced highest yield in August and lowest yield in May. Similarly, Rampur Composite produced highest yield in August and lowest yield in May. In the same way Gaurav produced highest in September and lowest in November. This result agree with finding by Otegui et al. (1995) that optimum planting date resulted in higher grain yield than early and late planting dates because of higher cob numbers and greater kernel numbers per plant). Variation in yield of corn varieties at different planting dates was associated with differences in the amount of intercepted radiation.

Highly significant interaction among year, variety and date of sowing (month) on grain yield of maize was obtained (Table 4). Arun-2 produced highest yield in August in both of years but lowest yield was in April (1.9 t/ha) in 2009 and in May (1.1 t/ha) in 2010. Rampur Composite produced highest yield in February in 2009 and in August in 2010 but lowest yield was in November in 2009 and in May of 2010. Gaurav produced highest yield in July in 2009 
and in September in 2010 but lowest yield was in November in 2009 and in May of 2010.

Table 3. Interaction effect of variety and date of sowing (month) on grain yield of maize in Rampur, Chitwan (2009-2010)

\begin{tabular}{llccc}
\hline S.N. & $\begin{array}{l}\text { Date of sowing } \\
\text { (month)(Month) }\end{array}$ & Arun-2 & $\begin{array}{c}\text { Variety } \\
\text { Rampur Composite }\end{array}$ & Gaurav \\
\hline 1. & April & 3.2 & 3.7 & 2.6 \\
2. & May & 2.1 & 2.6 & 2.4 \\
3. & June & 2.3 & 2.7 & 4.2 \\
4. & July & 3.2 & 4.3 & 4.8 \\
5. & August & 4.6 & 6.1 & 4.6 \\
6. & September & 4.0 & 4.8 & 5.1 \\
7. & October & 3.5 & 4.4 & 3.7 \\
8. & November & 3.2 & 3.3 & 1.5 \\
9. & December & 2.6 & 3.6 & 3.1 \\
10. & January & 2.4 & 3.2 & 2.5 \\
11. & February & 4.5 & 5.4 & 4.9 \\
12. & March & 4.1 & 4.8 & 4.3 \\
\hline
\end{tabular}

LSD at $0.05=1.129$

SEM $=0.4057$

$P$ value $=0.05$

Table 4. Interaction effect of year, variety and date of sowing (month) on grain yield of maize in Rampur, Chitwan

\begin{tabular}{|c|c|c|c|c|c|c|c|}
\hline \multirow{3}{*}{ S.N. } & \multirow{3}{*}{$\begin{array}{l}\text { Date of } \\
\text { sowing } \\
\text { (month)(M } \\
\text { onth) }\end{array}$} & \multicolumn{6}{|c|}{ Variety and Year } \\
\hline & & \multicolumn{2}{|c|}{ Arun-2 } & \multicolumn{2}{|c|}{ Rampur Composite } & \multicolumn{2}{|c|}{ Gaurav } \\
\hline & & 2009 & 2010 & 2009 & 2010 & 2009 & 2010 \\
\hline 1. & April & 1.9 & 4.4 & 2.9 & 4.5 & 3.3 & 1.8 \\
\hline 2. & May & 3.1 & 1.1 & 3.6 & 1.6 & 3.7 & 1.2 \\
\hline 3. & June & 2.1 & 2.5 & 2.8 & 2.7 & 5.3 & 3.1 \\
\hline 4. & July & 4.0 & 2.4 & 3.6 & 5.1 & 6.6 & 3.0 \\
\hline 5. & August & 4.4 & 4.9 & 4.6 & 7.5 & 6.0 & 3.3 \\
\hline 6. & September & 3.1 & 4.8 & 4.8 & 4.8 & 5.5 & 4.8 \\
\hline 7. & October & 3.9 & 3.1 & 4.4 & 4.3 & 4.6 & 2.8 \\
\hline 8. & November & 2.4 & 3.9 & 2.3 & 4.2 & 1.1 & 1.9 \\
\hline 9. & December & 2.5 & 2.7 & 3.3 & 4.0 & 1.2 & 5.0 \\
\hline 10. & January & 3.2 & 1.5 & 4.5 & 1.9 & 3.6 & 1.4 \\
\hline 11. & February & 5.1 & 4.0 & 6.7 & 4.1 & 6.4 & 3.3 \\
\hline 12. & March & 4.3 & 4.0 & 4.8 & 4.7 & 4.6 & 4.0 \\
\hline \multicolumn{8}{|c|}{ LSD at $0.05=2.104$} \\
\hline \multicolumn{8}{|c|}{ SEM $=0.5738$} \\
\hline \multicolumn{8}{|c|}{$P$ value $=0.01$} \\
\hline
\end{tabular}

BK et al. (2015) reported that grain yield of maize was affected by genotypes and date of planting at Rampur Chitwan Nepal. Lesser grain August was due to less population because a lot of plants were lodged due to the rainy season in month of August. Optimum sowing date 
resulted in higher grain yield than early and late planting dates (Otegui et al. (1995). The result are in confirmation with Jaliya et al. (2008), Namakka et al. (2008), Aziz et al. (2007), Khan et al. (2002) and Zaki et al. (1994) who reported that grain yield was reduced by delay in sowing.

\section{Conclusions}

Based on the result of this experiment it can be concluded that the higher grain yield in Rampur Composite, Gaurav and Arun-2 can be obtained by planting them in early winter season especially in the month of August in terai region of Nepal.

\section{Acknowledgments}

The authors gratefully acknowledge financial support from Nepal Agricultural Research Council, Nepal.

\section{References}

Aziz, A., Rahman, H. \& Khan, N. 2007. Maize cultivar response to population density and planting dates for grain and biomass yield. Sarhad J. Agric. 23(1): 25-30.

B.K., S. B., Karki, T.B. , Shrestha, J. \& Adhikari, P. 2015. Productivity of maize genotypes under different planting dates. Our Nature. 13(1): 45-49. DOI: http://dx.doi.org/10.3126/ on.v13i1.14208

Carangal, V.R., Ali, S.M., Koble, A.F., Rinke, E.H. \& Sentz, J.C. 1971. Comparison of S1 with testcross evaluation for recurrent selection in maize. Crop Science, 11: 658-661.

Chaudry, F.M. 1994. Kharif Cereal Crops in Crop Production. National Book Foundation, Islamabad, pp: 262. Chitwan, Nepal.

Dahmardeh, M. \& Dahmardeh, M. 2010. The Effect of sowing date and some growth physiological index on grain yield in three maize hybrids in south eastern Iran. Asian Journal of Plant Sciences, 9: 432- 436.

Ismail, A.A. 1996. Gene action and combining ability for flowering and yield in maize under two different sowing dates. Assiut J. Agric. Sci., 27: 91-105.

Jaliya, M.M., Falaki, A.M., Mahmud, M. \& Sani, Y.A. 2008. Effect of sowing date and NPK fertilizer rate on yield and yield components of quality protein maize (Zea mays L.). ARPN J. Agric. Bio. Sci. 3(2): 23-29.

Khan, H., Arif, M., Gul, R., Ahmad, N. \& Khan, I.A. 2002. Effect of sowing dates on maize cultivars. Sarhad J. Agric. 18(1): 11-15.

Mascagni, Jr. H.J. \& Boquet, D.J. 1996. Starter fertilizer and planting date effects on corn rotated with cotton. Agron. J., 88: 975-982.

MoAD. 2016. Statistical information on Nepalese agriculture, 2015/2016 (2072/2073). Agribusiness Promotion and Statistics Division, Singha Durbar, Kathmandu, Nepal.

Namakka, A., Abubakar, I.U., Sadik, A.I., Sharifai, A.I. \& Hassas, A.H. 2008. Effect of sowing date and nitrogen level on yield and yield components of two extra early maize varieties (Zea mays L.) in Sudan Savanna of Nigeria. ARPN J. Agric. Bio. Sci. 3(2):1-5.

NMRP. 2011. Annual Report 2010-11. National Maize Research Program, Raampur,

Otegui, M.E., Nicolini, M.G. , Ruiz, R.A. \& Dodds, P.A. 1995. Sowing date effects on grain yield components for different maize genotypes. Agronomy Journal, 87: 29-33.

Sadek, S.E., El-Sherbieny, H.Y.S., Ahmed, M.A. \& Younis, M.A. 1994. Evaluation of eight yellow maize (Zea mays L.) hybrid grown in Egypt. Growth analysis and grain yield components. Journal Agriculture Science Mansoura University, 19: 4154-4160. 
Shrestha, J., Koirala, K., Katuwal, R., Dhami, N., Pokhrel, B., Ghimire, B., Prasai, H., Paudel, A., Pokhrel, K., and KC, G. 2015. Performance evaluation of quality protein maize genotypes across various maize production agro ecologies of Nepal. Journal of Maize Research and Development, 1(1): 21-27.

Tanaka, A. \& Hara, T. 1974. Studies on the nutrio-physiology of maize plant. 10. Grain yield affected by sowing date. Fld. Crop abstr. 27: p. 565

Zaki, M.S., Shah, P. \& Hayat, S. 1994. Effect of sowing date on maize and non-flooded land rice. Sarhad J. Agric. 10(2): 191-199.

Zaki, N.M., El-Gazzar, M.M., Gamal, K.M. \& Ahmed, M.A. 1999. Partition and migration of photosynthesis in some maize hybrids. Egyption Journal Application Science, 14: 117139. 